\title{
Strategies to Facilitate the Transition of \\ Preschoolers from Kindergarten to School
}

Diana-Crina Marin, Mușata Bocoș, Liliana-Camelia Mărginean, Ionela-Lucia Șeulean 


\title{
Strategies to Facilitate the Transition of Preschoolers from Kindergarten to School
}

\author{
Diana-Crina Marin ${ }^{a *}$, Mușata Bocoș ${ }^{\mathrm{b}}$, Liliana-Camelia Mărginean ${ }^{\mathrm{c}}$, Ionela-Lucia \\ Şeulean ${ }^{\mathrm{d}}$ \\ a Doctoral School "Education, Reflection, Development”, Babes-Bolyai University Cluj-Napoca, 7 Sindicatelor Street, 400029, Romania \\ ${ }^{b}$ Babes-Bolyai University, Faculty of Psychology and Educational Sciences, Babes-Bolyai University Cluj-Napoca, 7 Sindicatelor Street, 400029, \\ Romania \\ "Kindergarten with Extended Program "Lumea Prichindeilor" Câmpia Turzii, 14 Parcului, 405100, Romania \\ ${ }^{d}$ Kindergarten with Extended Program "Pinocchio" Câmpia Turzii, 8 Retezatului, 405100, Romania \\ *Corresponding author: crinadiana88@yahoo.com
}

\section{Abstract}

\section{Keywords:}

School adaptation kindergarten, effective strategies, preschool level.
The purpose of this study was to establish the main strategies that teachers could apply during preschool education in order to facilitate the transition from kindergarten to school. Data were collected using an online questionnaire designed by us. 238 preschool education teachers have filled in the questionnaire. The main strategies used in order to facilitate the preschoolers' adaptation to the school demands are visits to other educational institutions from their hometown, organizing workshops, in collaboration with primary school teachers, organizing meetings with pupils and primary school teachers, organizing didactic activities or educational workshops for parents and preschoolers, as a context for parents to present various school experiences or reading stories about school and the pupils' life. We have also discovered that in the opinion of most of the teachers, school adaption is an easy process for most preschoolers. For some of the preschoolers, this process could be difficult, and the actions of parents, teachers, and school counselors could be very helpful. The results of this study are useful for primary school teachers, teachers for preschool education, or researchers in the educational field interested in optimizing the transition of children from kindergarten to school.

\section{Zusammenfasung}

\section{Schlüsselworte:}

Schulanpassung Kindergarten, effektive Strategien,

Vorschulstufe.
Das Ziel dieser Studie war es, die wichtigsten Strategien zu bestimmen, die von Lehrern für die Vorschulerziehung angewendet werden können, um den Übergang vom Kindergarten in die Schule zu erleichtern. Die Daten wurden mittels eines von uns konzipierten Online-Fragebogens erhoben. 238 Lehrkräfte für Vorschulerziehung haben den Fragebogen ausgefüllt. Die wichtigsten Strategien, um die Anpassung der Vorschulkinder an die schulischen Anforderungen $\mathrm{zu}$ erleichtern, sind Besuche bei anderen Bildungseinrichtungen aus ihrer Heimatstadt, die Organisation von Workshops in Zusammenarbeit mit Grundschullehrern, die Organisation von Treffen mit Schülern und Grundschullehrern, die Organisation von didaktischen Aktivitäten oder pädagogischen Workshops für Eltern und Vorschulkinder, als Kontext für Eltern, um verschiedene Schulerfahrungen zu präsentieren oder Geschichten über die Schule und das Leben der Schüler zu lessen. Wir haben auch festgestellt, dass nach Meinung der meisten Lehrer die Anpassung an die Schule für die meisten Vorschulkinder ein einfacher Prozess ist. Für einige Vorschulkinder könnte dieser Prozess schwierig sein, und die Maßnahmen von Eltern, Lehrern und Schulberatern könnten sehr hilfreich sein. Die Ergebnisse dieser Studie sind nützlich für Grundschullehrer, Vorschullehrer oder Forscher im Bildungsbereich, die daran interessiert sind, den Übergang von Kindern vom Kindergarten in die Schule zu optimieren.

\section{Introduction}

The accommodation with the demands of the school is a very important process. Children's first experiences in the school space should be positive. The interactions with the primary school teachers and the social relationships with colleagues are also very important. The process of transition from kindergarten to school is facilitated by the actions made by the teachers for preschool education and by the strategies used. The positive interactions with primary school pupils or primary school teachers are also salient. In this article, we have made an inventory of the most effective strategies that teachers for preschool education have used or intend to use to facilitate the children's transition from kindergarten to school. 


\section{Theoretical foundation}

The process of school adaptation can be facilitated through an authentic collaboration between school and family and an optimal involvement of the family in children's education (Zhao, 2017; Tan \& Goldberg, 2009; Correia \& Marques-Pinto, 2016). The socioeconomic status of the family, the parental style adopted by the family, the learning experience carried out in the family, the level of children's self-esteem, the degree of development of children's emotional intelligence, and the ability to relate to others are also important factors (Akçinar, 2013; Vlaicu, Anghel \& Voicu, 2019; Jung, 2016). Authors of recent studies have outlined the importance of the family's positive actions and attitudes (Vlaicu, Anghel \& Voicu, 2019; Akçinar, 2013; Miller-Lewis, Sawyer, Searle \& Sawyer, 2014). The positive parenting styles have positive effects on children's development, and at the same time on the school adaptation process (MillerLewis, Sawyer, Searle \& Sawyer, 2014). "The child should be encouraged to explore and experience new activities and situations; placing him in such situations he gains the courage and confidence that he needs to overcome everyday obstacles and difficulties and develop personal autonomy" (Vlaicu, Anghel \& Voicu, 2019, p. 1399).

At the same time, teachers for preschool education have an important role in facilitating the transition of children from kindergarten to school, being necessary for them to create a stimulating educational environment, favourable to good cognitive, emotional, and social development (Vlaicu, Anghel \& Voicu, 2019). "The school readiness and adaptation should be considered together with all developmental areas, rather than just cognitive competence." (Akçinar, 2013, p. 1103). Children's social interaction skills are extremely important and have a positive impact on their school adaptation (Goble et al., 2017). "The first month after primary school enrollment should be set as a study preparation period. Meanwhile, the last two months of kindergarten classes should also be set as preparatory a period" (Zhao, 2016, p. 432).

Preschools institutions organize various programs, projects, or educational activities, through which children can be supported in the process of adaptation to school requirements (Marcineková, Borbélyová \& Tirpáková, 2020). These programs should pay special attention to children's emotional development and relationship skills. It is beneficial for preschoolers to come into contact with the school environment and participate in various reading activities or learning contexts that allow them to interact with primary school teachers or students (Ólafsdóttir \& Einarsdottir, 2019; Sobczak, 2017). "Kindergarten should cooperate with families and communities to interact with primary schools." (Zhao, 2016, p. 432).

\section{Research methodology}

In this article, we would like to find the answer to the following question: Which strategies are efficient to facilitate the children's accommodation with the demands of the school? The questionnaire included in Appendix 1 was filled in the school year 2020-2021 by 238 teachers for preschool education in Romania. The online questionnaire contains 4 items and was designed in order to collect data about the preschoolers' transition from kindergarten to school.

\section{Results}

The first question of the questionnaire was formulated with the purpose to establish how difficult the process of accommodation to the demands of the school is for preschoolers. According to teachers' opinion, for most preschoolers, school accommodation is a natural process. The teachers who have selected another answer mentioned that the transition from kindergarten is perceived by children in individual ways, and the factors that influence the children's accommodation with the school demands are very different. Some of their personality characteristics are also important in this process. Thus, school accommodation could be a very simple process for some children, but at the same time, can be a very complicated process for others. Most of the children are enthusiastic, but some of them are feeling scared about the changes generated by their new roles and responsibilities. At the same time, the teachers for preschool education mentioned that the family plays a very important role in the process of school accommodation. The discussions with the parents about the changes generated by their new roles are of paramount importance. The kindergarten's environment is created in order to prepare children for a good adaptation to the demands of the school. According to the teachers who teach at the preschool level most of the children are very enthusiastic about de fact that they are becoming pupils (see Figure 1). 
Figure 1. Teachers' opinion regarding the process of accommodation with the school demands

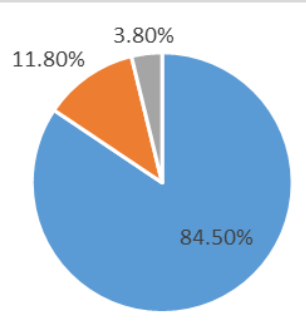

- Natural, because preschoolers want to become pupils

- Difficult or very difficult because children are very attached to the kindergarten environment and educators

= Another answer

To prepare and facilitate the transition of preschoolers from kindergarten to school, teachers for preschool education consider that various educational activities should be carried out such as visits to other educational institutions from their hometown, organizing workshops, in collaboration with primary school teachers, organizing meetings with pupils and primary school teachers, organizing didactic activities or educational workshops for parents and preschoolers, as a context for parents to present various school experiences, and reading stories about school and the life of the pupils. Other strategies which can ensure the continuity between kindergarten and school demands are the simulation of a school day (organizing furniture in the form of benches, recognizing and using writing instruments and other supplies, getting acquainted with some notions from the preparatory class such as letters or numbers, etc.), and organizing educational workshops with the participation of preschoolers and their parents (see Figure 2).

Figure 2. Effective strategies that will be used in the future by teachers for preschool education

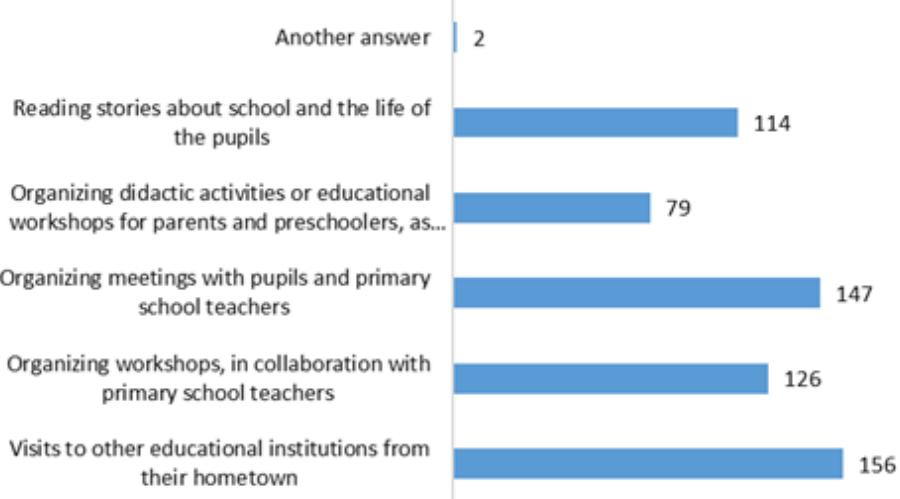

With the purpose to prepare and facilitate the transition of preschoolers from kindergarten to school, teachers for preschool education have carried out various educational activities (see Figure 3).

Figure 3. Effective strategies that were used before by teachers for preschool education

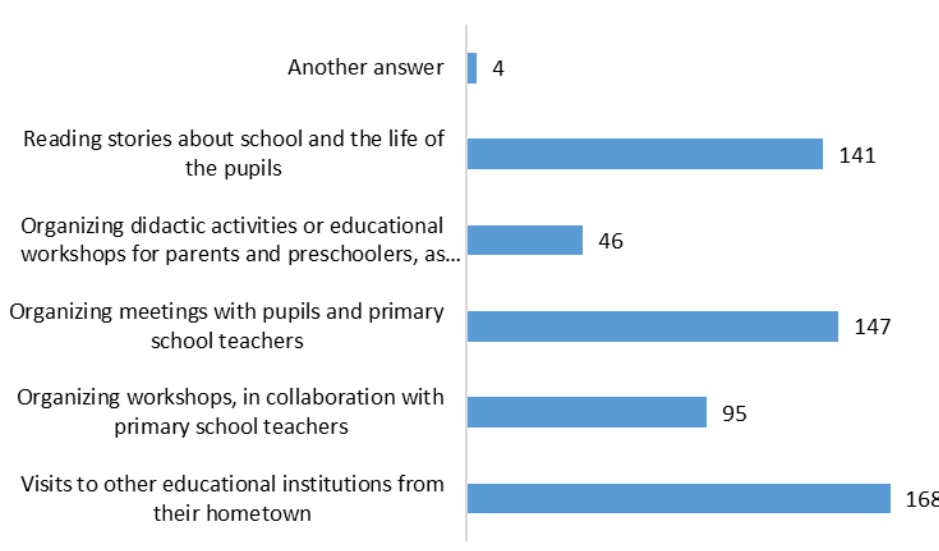

The project "Let's get ready for school!", during which are simulated various school contexts, was mentioned by some of the respondents as being very beneficial. Activities based on discussions about school events and school supplies, picture reading activities, activities carried out together with the school counsellor, the end of the school year celebrations, activities based on reading stories and poems about school and school habits are considered effective. The teachers for preschool education have mentioned that they have read aloud various books written by Romanian and foreign writers. The most recommended books/ resources used by teachers for preschool education are Aricilă goes to school (written by Heidi și Daniel Howarth) and Jake's first day of school (Twinkle Originals Stories).

Individual/group discussions with parents of preschoolers were also initiated by the teachers or counsellors from kindergarten. Organizing role-plays and dramatizations, discussing school experiences with guests (parents, pupils, teachers, or other members of the community), or singing songs about school or pupils' life were mentioned as positive strategies. Teachers have also organized debates about classroom rules, have initiated active partnerships kindergarten-school (in which preschoolers had the opportunity to visit the class, to sit in the bank, to carry out artistic-plastic activities with pupils or fun games). Other strategies mentioned by teachers for preschool education are activities in which the positive preparation of the children takes place. Some of the teachers mentioned that they read therapeutic stories 
to preschoolers (in order to help them understand their emotions, to help them overcome them, and to facilitate their adaptation to school). Also, preschoolers were encouraged to create stories based on photos from the school environment.

\section{Discussions and conclusions}

It would be useful to establish which are the main actions realized by primary school teachers at the beginning of the preparatory grade to facilitate the school adaptation of preschoolers. It is also important that both primary school teachers and teachers for preschool education cooperate with parents and school counsellors to smooth the path of the accommodation process of preschoolers with the school demands. Future studies could study the views of preschoolers and parents of preschoolers on the activities that can be organized to facilitate the transition from kindergarten to school. The COVID-19 pandemic had major effects on the content and the type of activities that could be organized in kindergarten. In the current epidemiological context, it would be useful to investigate which activities were successful in the online environment with the purpose to facilitate the transition of children from kindergarten to school.

\section{Appendix A.}

\section{Questionnaire Strategies that facilitate the transition of preschoolers from kindergarten to school}

Through this questionnaire, we aim to identify effective strategies and activities that can facilitate the adaptation of preschoolers to school requirements.

1. For most preschoolers, the transition from kindergarten to school is a process:

$\ulcorner\quad$ Natural, because preschoolers want to become pupils

$\Gamma \quad$ Difficult or very difficult because children are very attached to the kindergarten environment and the educators

$\Gamma \quad$ Other response

2. What strategies to ensure the continuity of the relationship between kindergarten and school do you consider to be effective and you would like to use in the future? (more possible answers)

$\ulcorner$ Visits to other educational institutions from their hometown

$\Gamma \quad$ Organizing workshops, in collaboration with primary school teachers

$\ulcorner$ Organizing meetings with pupils and primary school teachers

$\ulcorner$ Organizing didactic activities or educational workshops for parents and preschoolers, as a context for parents to present various school experiences

$\Gamma \quad$ Reading stories about school and the life of the pupils

$\Gamma$ Other answer:

3. What educational activities have you organized over time to prepare and facilitate the transition of preschoolers from kindergarten to school? (more answers possible)

$\ulcorner\quad$ Visits to other educational institutions from their hometown

$\Gamma$ Organizing workshops, in collaboration with primary school teachers

$\ulcorner$ Organizing meetings with pupils and primary school teachers

$\Gamma$ Organizing didactic activities or educational workshops for parents and preschoolers, as a context for parents to present various school experiences

$\ulcorner\quad$ Reading stories about school and the life of the pupils

$\Gamma$ Other answer: 
4. What stories/books or poems about student life or the school environment have you to the preschoolers to help children adapt to school requirements?

\section{Authors note:}

The authors have equal contributions to this article.

Diana-Crina Marin is currently a teacher at "Pavel Dan" Theoretical High School, in Câmpia Turzii and a postdoctoral researcher at Babeș-Bolyai University. Her research areas are aimed to find innovative modalities to consolidate the school-family partnership, considering that the school and family should be real partners regarding the children's education. She is also interested in finding the most effective teaching practices that could be successfully used in the educational process.

Mușata Bocoș is a University Professor and Ph.D. Coordinator at the Faculty of Psychology and Sciences of Education (Babeș-Bolyai University, Cluj-Napoca, Romania). In 1997, she obtained a PhD in Educational Sciences, at Babeș-Bolyai University. Her research interests are reflected in a series of studies and articles published in important national and international journals. Her teaching activity covers several areas, such as curriculum theory and methodology, general didactics, and educational research.

Liliana-Camelia Mărginean is a director at Kindergarten with Extended Program "Lumea Prichindeilor" Câmpia Turzii, from Câmpia Turzii, Cluj County. She is carrying out his managerial activity with passion and responsibility. She is interested in sharing experiences with other kindergartens, exploring new positive teaching experiences, and involving children and teachers in interesting learning activities.

Ionela-Lucia Seulean is a director at Kindergarten with Extended Program "Pinocchio" Câmpia Turzii, from Câmpia Turzii, Cluj County. She considers it important to show confidence in the employees' abilities and to motivate them for continuous training. Also, she is preoccupied to create an optimal educational climate for all the 292 wonderful preschoolers, who are enrolled in kindergarten. She carries out the activity of institutional management with love and passion, respecting the legislation in force.

\section{References}

Akçinar, B. (2013). The predictors of School adaptation in early childhood. Procedia - Social and Behavioral Sciences, 93, doi:10.1016/j.sbspro.2013.09.338.

1099-1104.

Correia, K., \& Marques-Pinto, A. (2016). Adaptation in the transition to school: Perspectives of parents, preschool and primary school teachers. Educational Research, 58(3), 247-264. doi:10.1080/00131881.2016.1200255.

Goble, P., Eggum-Wilkens, N., Bryce, C., Foster, S., Hanish, L., Martin, C., \& Fabes, R. (2017). The transition from preschool to first grade: A transactional model of development. Journal of Applied Developmental Psychology, 49, 55-67. doi: 10.1016/j.appdev.2017.01.007.

Marcineková, T., Borbélyová, D., \& Tirpáková, A. (2020). Optimization of Children'S transition from preschool and family environment to the first grade of primary school in Slovakia by implementation of an Adaptation programme. Children and Youth Services Review, 119, 105483. doi:10.1016/j.childyouth.2020.105483.

Miller-Lewis, L. R., Sawyer, A. C., Searle, A. K., \& Sawyer, M. G. (2014). Child and family predictors of child-teacher relationship trajectories during the transition from preschool to school. International Journal of Information and Education Technology, 4(3), 235-243. doi:10.7763/ijiet.2014.v4.405.

Ólafsdóttir, S. M., \& Einarsdottir, J. (2019). Following children's advice on transitions from preschool to primary school. Listening to Children's Advice about Starting School and School Age Care, 69-83. doi:10.4324/9781351139403-6.

Sobczak, S. (2017). The importance of parent reading of various literary texts in developing children's emotional and social school readiness. ICERI2017 Proceedings. doi:10.21125/iceri.2017.1070.

Jung, E. (2016). The development of reading skills in kindergarten influence of parental beliefs about school readiness, family activities, and children's attitudes to school. International Journal of Early Childhood, 48(1), 61-78. https://doi.org/10.1007/s13158-016-0156-2

Tan, E. T., \& Goldberg, W. A. (2009). Parental school involvement in relation to children's grades and adaptation to school. Journal of Applied Developmental Psychology, 30(4), 442-453. doi:10.1016/j.appdev.2008.12.023. 
Vlaicu, C., Anghel, A. G., Voicu, C. D. (2019). The importance of raising pre-school children self-esteem in assuring successful school adaptation. doi:10.15405/epsbs.2019.08.03.171.
Zhao, X. (2017) Transition from Kindergarten to Elementary School: Shanghai's Experience and Inspiration. Creative Education, 8, 431-446. doi: 10.4236/ce.2017.83033. 